\title{
WATER QUALITY AND PERIPHYTON COMMUNITY OF A STREAM SYSTEM RECEIVING MUNICIPAL WASTE DISCHARGES IN RIVERS STATE, NIGER DELTA, NIGERIA
}

\author{
Avaliação da qualidade da água e da comunidade de perifíton \\ em um sistema de córregos receptor de descargas de esgotos \\ municipais no estado de Rivers, Delta do rio Níger, Nigéria
}

\author{
Alex Chuks Chindah ${ }^{1}$ \\ Solomon Amabraye Braide ${ }^{2}$ \\ Florence Obianefo ${ }^{3}$ \\ Charles Chuku Obunwo ${ }^{4}$
}

\begin{abstract}
The water quality and periphyton parameters were investigated at 5 designated stations along Ntawogba stream system that lies within the Port Harcourt metropolis located between latitude $4^{\circ} 5^{\prime \prime} \mathrm{N}$ and $5^{\circ} 00^{\prime \prime} \mathrm{N}$ and longitude $6^{\circ} 55^{\prime \prime} \mathrm{E}$ and $7^{\circ} 00^{\prime \prime E}$. Sampling was done for dry (January - March2004) and wet (June - August 2004) seasons using standard procedures. Samples were collected at the designated stations along the water course for physicochemical (temperature, $\mathrm{pH}$, conductivity, alkalinity $\mathrm{DO}, \mathrm{BOD}_{5}, \mathrm{NO}_{3}^{-}, \mathrm{NH}_{3}^{-}, \mathrm{PO}_{4}^{3}, \mathrm{SO}_{4}^{2}$ ) and periphyton descriptors (species richness, species diversity, abundance, biomass, and productivity). The spatio-temporal differences for the parameters were evaluated and the physicochemical attributes demonstrated spatial and seasonal trends but were essentially not statistically significant while the periphyton descriptors demonstrated seasonal and spatial differences and are more reliably affected by the waste water discharges.
\end{abstract}

Keywords: Water quality; Periphyton; Port harcourt; Physicochemical parameters; Descriptors; Discharges.

\section{Resumo}

A qualidade da água e parâmetros de perifiton foram estudados em 5 estações designadas ao longo do sistema de córregos de Ntawogba que se encontra dentro da metrópole de Port Harcourt, localizada entre as latitudes $4^{\circ}$ $5^{\prime \prime} \mathrm{N}$ e $5^{\circ} 00^{\prime \prime} \mathrm{N}$, e as longitudes $6^{\circ} 55^{\prime \prime} \mathrm{L}$ e $7^{\circ} 00^{\prime \prime} \mathrm{L}$. As amostragens foram coletadas na estação seca (janeiro-março 2004) e na estação chuvosa (junho-agosto 2004) usando-se procedimentos padrão. As amostras eram coletadas nos locais designados ao longo do curso d'água para análises físico-químicas (temperatura, pH, condutividade, alcalinidade, $\mathrm{OD}, \mathrm{BOD}_{5}, \mathrm{NO}_{3}^{-}, \mathrm{NH}_{3}^{-}, \mathrm{PO}_{4}^{-3}, \mathrm{SO}_{4}^{-2}$ ) e análises do perifíton (riqueza de espécies, diversidade de espécies, abundância, biomassa e produtividade). As diferenças espaço-temporais para os parâmetros foram avaliadas e os atributos físico-químicos demonstraram direções espaciais e sazonais, mas não foram significantes estatisticamente, enquanto as análises de perifíton demonstraram diferenças sazonais e espaciais e são mais afetados pela descarga de dejetos na água.

Palavras-chave: Qualidade da água; Perifíton; Port harcourt; Parâmetros físico-químicos; Biomarcadores; Esgoto.

\footnotetext{
Researchers from Institute of Pollution Studies. Correspondence author - E-mail: alexchindah@hotmail.com.

Researchers from Institute of Pollution Studies.

Researchers from Institute of Pollution Studies.

Researchers from Institute of Pollution Studies. Chemistry Department, Rivers State University of Science and Technology, P M B 5080, Port harcourt, Rivers State, Nigeria.
} 


\section{Introduction}

In recent times the problem of water pollution has been of concern to all stakeholders, following the rate and extent of degeneration of environment and water bodies by human activities, particularly from industrial and domestic sources. The oil exploration and exploitation activities in the Niger Delta have increased the surge of human population to major activity areas in the region and one of the major cities being Port Harcourt. These population growths have inadvertently increased effluents and solid wastes generated and discharged into the environment, which finally find their way into the natural water bodies. One such water bodies is a perennial urban swamp forest stream that meanders through the city centre and empties into the Bonny estuaries through Amadi creek. The impact of these discharges on the freshwater body is relatively unknown (1, 2, 3, 4). Recent studies in similar water bodies receiving municipal discharges have limited scope as emphasis had been on physicochemical characteristics with little emphasis on the biological features such as the primary producers $(4,5)$. The studies that have placed emphasis on the effect of oil industrial activities on water quality and the biological attributes (6) have rather on brackish water systems $(1,7,8)$. The major and critical water qualities were not considered in these studies. When such studies were conducted, they were for a very short duration and hardly can the information be used to effectively characterize and determine the effect of the waste on the water quality and biota. It is on the basis of this, that critical physicochemical and biological attributes such as chlorophyll 'a', primary productivity and species identification have been used in order to characterize and identify indicator species for the water body, and to understand and monitor changes in watershed ecosystem.

\section{Materials and methods}

\section{Study Area}

The stream (Nta-Wogba) is located on the western flank of Port Harcourt city of the Rivers State, Nigeria. The stream lies between latitude $4^{\circ} 5^{\prime \prime} \mathrm{N}$ and $5^{\circ} 00^{\prime \prime} \mathrm{N}$ and longitude $6^{\circ} 55^{\prime \prime} \mathrm{E}$ and $7^{\circ} 00^{\prime} \mathrm{E}$ (Fig.1). The climate of the area is basically that of tropical equatorial latitude with rainfall occurring almost all year round (9). The Nta-wogba stream is a black water stream with its head water draining the Ora-Azi forest and meanders through the densely Port Harcourt city into the Bonny estuary. It is exposed to increasing amount of urban wastes as it flows seaward, which are mainly from garages, domestic discharges, wastes from markets and construction sites. The upper limit of the stream constitutes (Stations 1\& 2) stations with low human population. The lower limit represented by Stations 3,4 and 5 that are within the densely populated area of the city. The human activities exert considerable pollution effect on the entire study area as it receives about 4500 litres/day of waste containing petroleum product especially as crankcase oil, over 250,000 litres/day of domestic waste are discharged, human waste of 80kg_day, 20kg_/day of metal/ and $58 \mathrm{~kg} /$ day of sold waste such as paper, polyethylene bags.

Samples were collected monthly for seven months. On each sampling period, samples for physicochemistry, phytoplankton and periphyton analyses were collected from five established stations (Stations1-5).

\section{Water quality}

Samples were collected with $2 \mathrm{ml}$ plastic containers at sub-surface level and analyzed in the Institute of Pollution Studies (IPS) laboratory using procedures as outlined in standard method for the examination of water and waste water (10). The following parameters were investigated: temperature, $\mathrm{pH}$, conductivity, alkalinity DO, $\mathrm{BOD}_{5}$, ammonia-nitrogen, nitrate-nitrogen, sulphate, phosphate. Concentrations of nitrate $\left(\mathrm{NO}_{3}^{-}\right)$, ammonia $\left(\mathrm{NH}_{3}^{-}\right)$, phosphate $\left(\mathrm{PO}_{4}^{3}\right)$, sulphate $\left(\mathrm{SO}_{4}{ }^{2}\right)$ were determine using the spectrophotometric method (Spectronic instrument 21D). Insitu measurement of termperature was made using mercury in bulb thermometer. pH was measured using the Hann instrument model HI8314. The conductivity was measured using the Horiba water checker model U10. Dissolved oxygen (DO) and Biochemical oxygen demand $\left(\mathrm{BOD}_{5}\right)$ were determined using Winkler's method. 


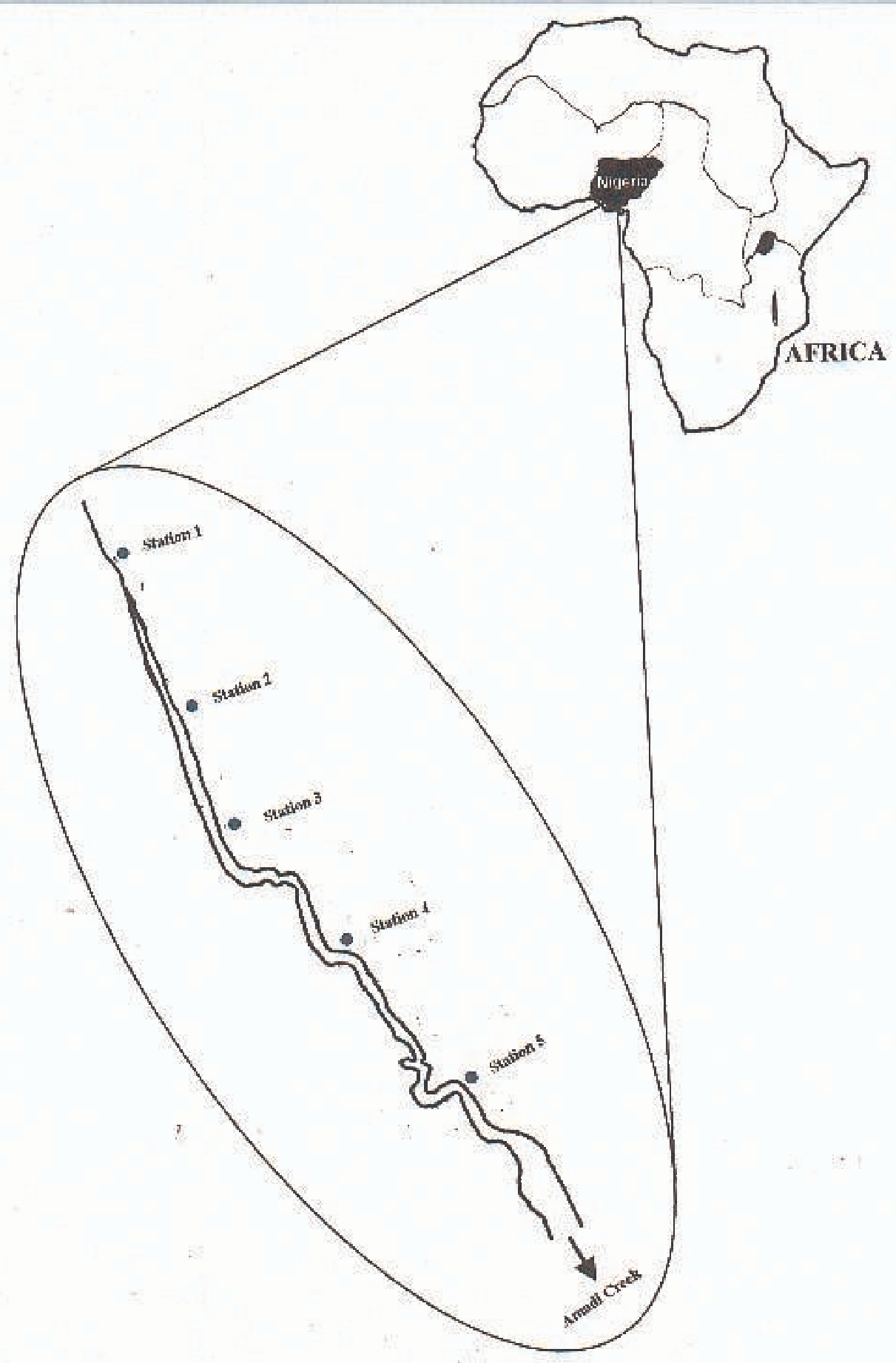

FIGURE 1 - Showing Africa, Nigeria and the sampling locations of the stream system 


\section{Periphyton}

For each station, the main descriptors of the periphyton community were sampled in triplicate with a quadrant of $3 \times 3 \mathrm{~cm}^{2}$ area from each station; 9 samples were collected for the 3 main descriptors of the periphyton community (i.e. species identification and enumeration, chlorophyll 'a' and primary productivity). All samples were collected from permanent submerged structures (concrete and logs). Scrapings within the marked quadrant area were carefully done with a sharp edged scalpel and emptied into the appropriate containers. The first 3 replicates were emptied into separate plastic vials, carefully marked $\left(\mathrm{A}_{1}-\mathrm{A}_{3}\right)$ and stored in an ice chest $\left(<4^{\circ} \mathrm{C}\right)$ for primary productivity assessment. The second replicate sets $\left(\mathrm{B}_{1}-\mathrm{B}_{3}\right)$ were emptied into 3 separate glass vials each containing $10 \mathrm{ml}$ of $90 \%$ acetone wrapped with foil for chlorophyll "a" analysis. The third sets of scrapings $\left(\mathrm{C}_{1}-\mathrm{C}_{3}\right)$ were also emptied into another 3 separate plastic vials containing $5 \mathrm{ml}$ of $10 \%$ formalin for species identification and numerical abundance estimates. The process was repeated for all the stations and stored properly before transferring to the laboratory for analysis. In the laboratory, the replicates marked $\mathrm{A}_{1}-\mathrm{A}_{3}$ were each subdivided into 3 sub replicates of equal weight using Mettler balance (model AE 166) then each of the replicate samples $\left(\mathrm{A}_{1-1}, \mathrm{~A}_{1-2}, \mathrm{~A}_{1-3,3}\right)$ were transferred into $100 \mathrm{~cm}^{3}$ Erlenmayer flasks which were then filled with filtered stream water and tightly stoppered. Three replicates of light and dark bottles (wrapped in aluminium foil) with sample were incubated in a trough containing the freshwater exposed under natural light and temperature condition. After $6 \mathrm{~h}$, of incubation the oxygen content in the flasks was measured using the Winkler azide method (10). The samples marked B for chlorophyll "a" were analyzed using the trichromatic method. Samples for numerical analysis were properly homogenized and $1 \mathrm{ml}$ sub-sample from original stock was collected with a sample pipette. The pipette content was transferred into a Sedge wick - Rafter counting chamber for enumeration using a Lietz binocular microscope magnification of 200x and identification of 1000x using the reports of Mills (11), Sieminka (12), Starmach (13), Patrick and Reimer (14) Durand and Leveque (15) and Chindah and Pudo (16). Samples for chlorophyll "a" were granulated in a mortar, centrifuged $O$ and the supernatant and blank analyzed using Spectronic instrument (model spectronic 21 D) as stated in APHA (10). Species richness and species diversity were calculated using the procedures of Margalef (17). Species richness $(\mathrm{SR})=(\mathrm{S}-1) / \mathrm{In} \mathrm{N}$, where $\mathrm{S}$ is the number of species and $\mathrm{N}$, the number of individuals in a sample and species diversity by the formula:

$$
\mathrm{H}^{\prime}=-\sum \mathrm{ni} / \mathrm{Nlog}_{2} \mathrm{ni} / \mathrm{N}
$$

The statistical analysis on student t- test and regression were performed using the Microsoft office Excel package 2003 software.

\section{Results}

\section{Water quality}

The summary of the physicochemical characteristics at the study station is contained in Fig. 2. The temperature indicated a narrow seasonal variation with minimum values of $24.6^{\circ} \mathrm{C}$ during the wet season and maximum of $27^{\circ} \mathrm{C}$ in the dry season. In all, wet season values ranged from $24.6{ }^{\circ} \mathrm{C}-25.4^{\circ} \mathrm{C}$ and dry season values ranged from $26.5^{\circ} \mathrm{C}-27.0^{\circ} \mathrm{C}$. Statistically, there were no significant differences between seasons using Student $\mathrm{t}$ - test, $\left(\mathrm{t}=3.91<\mathrm{P}=2.02_{(0.05)}\right.$. The $\mathrm{pH}$ values ranged from $6.25-6.95$ across the stations over the study period. All the stations demonstrated the same distribution pattern. Wet season values ranged from $6.28-6.51$ and dry season values ranged from 6.58-6.95. The dry season values were slightly higher than that of those of wet season, however the differences between the seasons were not significant (student $\mathrm{t}$ - test. $-\mathrm{t}=2.01<\mathrm{P}=2.015$ (0.05) Electrical conductivity ranged from 165.8 $306 \mathrm{~ms} / \mathrm{cm}$ for the entire study period and values for dry season $(170.3-306 \mathrm{~ms} / \mathrm{cm})$ were higher than those of the wet season $(165.8-274 \mathrm{~ms} / \mathrm{cm})$ and stations at the lower stretch of stream tended to exhibit higher conductivity values than the upper reach stations. The differences between seasons were also not statistically significant (student t- test, $\mathrm{t}=0.60<\mathrm{P}=2.015_{(0.05)}$. Alkalinity concentrations ranged from $50.76-114.7 \mathrm{mg} / \mathrm{l}$. Dry season concentrations $(50.7-114.7 \mathrm{mg} / \mathrm{l})$ were higher than wet $(65.5-85 \mathrm{mg} / \mathrm{l})$ season values (except for station 2) but the differences between seasons were not significant (Student t- test, $\mathrm{t}=0.62<\mathrm{P}=2.015_{(0.05)}$ ). 
Dissolved oxygen concentrations were generally low for the entire study period and concentrations ranged from $1.89-5.08 \mathrm{mg} / 1$. Concentrations for wet $\operatorname{season}(2.74-5.08 \mathrm{mg} / \mathrm{l})$ were higher than in the dry season (1.89 -3.25mg/1). Station 2 consistently recorded the highest concentration for both seasons. Statistically, the seasonal differences were not significant (Student t- test, $\mathrm{t}=0.95<\mathrm{P}=2.015_{(0.05)}$ ). The Biochemical oxygen demand $\left(\mathrm{BOD}_{5}\right)$ concentration for the study period varied from 1.00 to $2.14 \mathrm{mg} / 1$. There were spatial variations in concentrations for both seasons with wet season concentrations (1.00- $1.89 \mathrm{mg} / \mathrm{l})$ being slightly lower than the observed during the dry season (1.42 $2.13 \mathrm{mg} / 1)$. Spatially, the $\mathrm{BOD}_{5}$ concentrations for both seasons tended to decrease down stream. Statistically there were no significant differences between seasons (Student t- test, $\mathrm{t}=0.51<\mathrm{P}=2.015_{(0.05)}$ ). Sulphate concentrations during the entire study period were considerably high $(2.05-5.17 \mathrm{mg} / \mathrm{l})$ and concentrations for the dry season (2.86- $4.88 \mathrm{mg} / \mathrm{l})$ were lower than concentrations obtained in the wet season (2.05$5.17 \mathrm{mg} / \mathrm{l}$ ) except in station 3). Spatial trends between seasons were not easily distinguishable, however, seasonal differences were not statistically significant (student t- test, $\mathrm{t}=0.42<\mathrm{P}=2.015_{(0.05)}$ ). Ammonia Nitrogen concentrations were relatively high with concentrations in the range of $0.06-2.35 \mathrm{mg} / 1$ for the study period. Wet season concentrations were uniformly low $(0.065-0.215 \mathrm{mg} / \mathrm{l})$ while dry season concentrations had higher values $(0.516-2.35 \mathrm{mg} / \mathrm{l})$ and the concentrations tended to increase down stream with Station 5 recording the maximum concentration for the season. The seasonal differences were not statistically significant ( Student $\mathrm{t}$ - test, $\mathrm{t}=$ $\left.0.31<\mathrm{P}=2.015_{(0.05)}\right)$. Nitrate - Nitrogen concentrations ranged from 0.17 to $1.8 \mathrm{mg} / \mathrm{l}$ for the study period. Wet season concentrations $(0.271-1.86 \mathrm{mg} / 1)$ were slightly higher than dry season values $(0.176-1.19 \mathrm{mg} / 1)$. The concentrations for both seasons tended to increase downstream. However, this differences between seasons were not statistically significant (Student t- test, $\left.\mathrm{t}=0.56)<\mathrm{P}=2.015_{(0.05)}\right)$. Phosphate concentrations that ranged from $0.11-1.35 \mathrm{mg} / 1$ for the entire study period, were low with the dry season concentrations (0.391 -1.348mg/1) higher than wet season values (0.106 $-0.154 \mathrm{mg} / \mathrm{l})$. In the dry season, concentrations increased down the stream while in wet season concentration were uniform across the stations. Statistically there were no significant differences between seasons (Student ttest, $\left.\mathrm{t}=1.95=<\mathrm{P}=2.015_{(0.05)}\right)$.

\section{Periphyton}

A total of 92 species were encountered, of these 39 species represented the family Bacillanophyceae, the contribution of species amongst the family groups demonstrated a decreasing species number in the order of Bacillariophyceae (39) > Cyanophyceae(19) = Chlorophyceae(19) > Euglenophceae(15). The most prominent species in the periphyton community were diatoms: Amphora sp., Achanthes gibberala, Eunotia curvatus, Gomphonema sp. Navicula pusilla w. smith, Nitzchia palea, green algae: Chosterium acerosim, $C$. closteriodes, $C$. lunula, and Cladophora oligodona;blue green algae Isocytis planktonia, Oscillatoria lumiosa, O. terebriformis and Euglenin Euglena caudate,and Trachelomonas elegans. Trachelomonas mirabilis and Euglena tripleris demonstrated narrow distribution and are restricted within the lower stretch of the stream (table 1).

The distribution of species number did not demonstrate spatial differences within the season. In dry season, the distribution of the number of occurring species in the stations ranged from a minimum of 63 species in station 1 to a maximum of 80 species in station 3 and the values were lower than those observed for the wet season which ranged from a minimum of 87 species in station 1 to 91 species in station 4 . The seasonal differences were statistically significant (student $\mathrm{t}$ - test, $\left.\mathrm{t}=2.42=<\mathrm{P}=2.015_{(0.05)}\right)($ Fig 3).

The Margalef's species richness followed the same pattern, observed for the number of species with higher values in wet $(10.66$ - 11.38) than in the dry season (8.32 - 9.78) and the seasonal differences were statistically significant (student $\mathrm{t}$ - test, $\mathrm{t}=2.21=<\mathrm{P}=$ $\left.2.015_{(0.05}\right)$. The Shannon Weaver species diversity $\left(H^{\prime}\right)$ did not demonstrate this consistent pattern for all the stations as the upper limit stations had dry season values almost higher than those of the wet season while the lower stretch limits had values slightly higher than that of the wet season, the values for wet and dry seasons ranged from 1.49 - 1.98 respectively (Fig 3). The periphyton community structure indicated that Bacillariophyceae constituted the bulk of the periphyton population for both seasons, such that in dry season the community structure demonstrated a dominance sequence of Bacillariophyceae -38.3\% > Cyanophyceae $-32.1 \%>$ Euglenophyceae (19.4\%) > Chlorophyceae $10.2 \%$. In wet season, the sequence order observed in the dry season was maintained (Bacillariophyceae 41.5\% > Cyanophyceae -29\% > Euglenophyceae -16.6\% 
$>$ Chlorophyceae -15.1\%). Nonetheless some stations exhibited a slight shift in the community structure from the general trend, for instance stations 1 and 5 showed distribution order of Bacillariophyceae $-20.58 \%>$ Cyanophyceae $-22.94 \%>$ Chlorophyceae $-15.01 \%>$ Euglenophyceae $-14.29 \%$ and Bacillariophyceae $-34.87 \%$
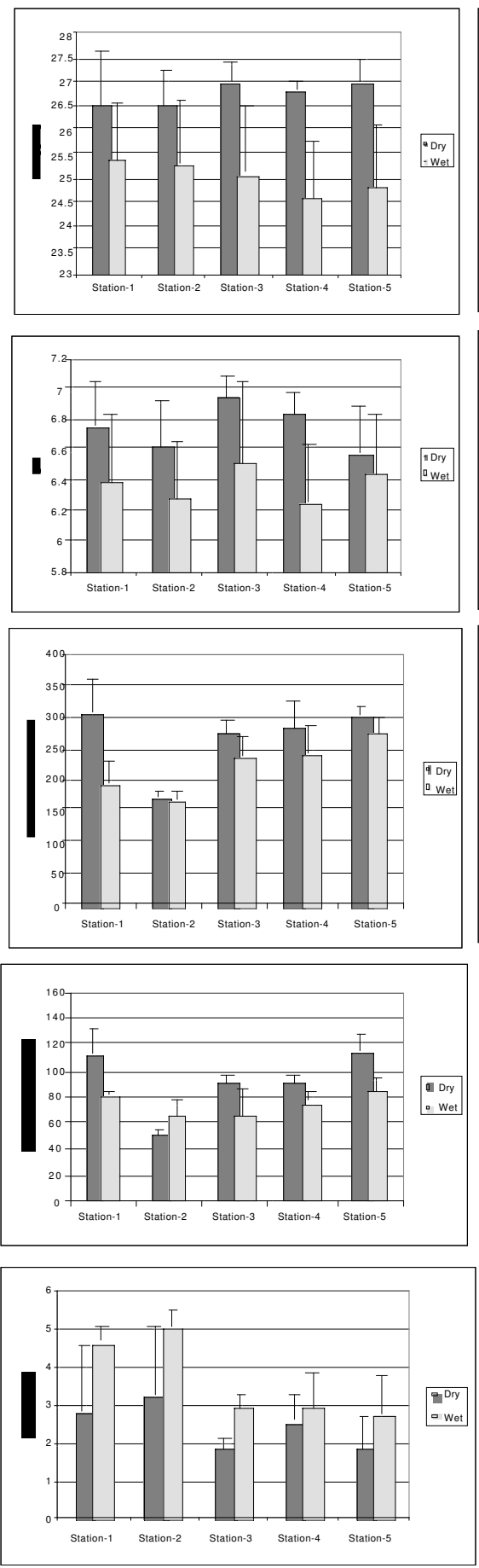

> Euglenophyceae -30.68\% > Cyanophyceae -30.68\% > Chlorophyceae- $3.77 \%$ respectively. Another shift from the general trend was observed at Stations 3 and 4 with a consistent community structure pattern of Cyanophyceae $-37 \%>$ Bacillariophyceae $-35.49 \%>$ Euglenophyceae 13.09\% > Chlorophyceae $-5.4 \%$ (Fig 4).
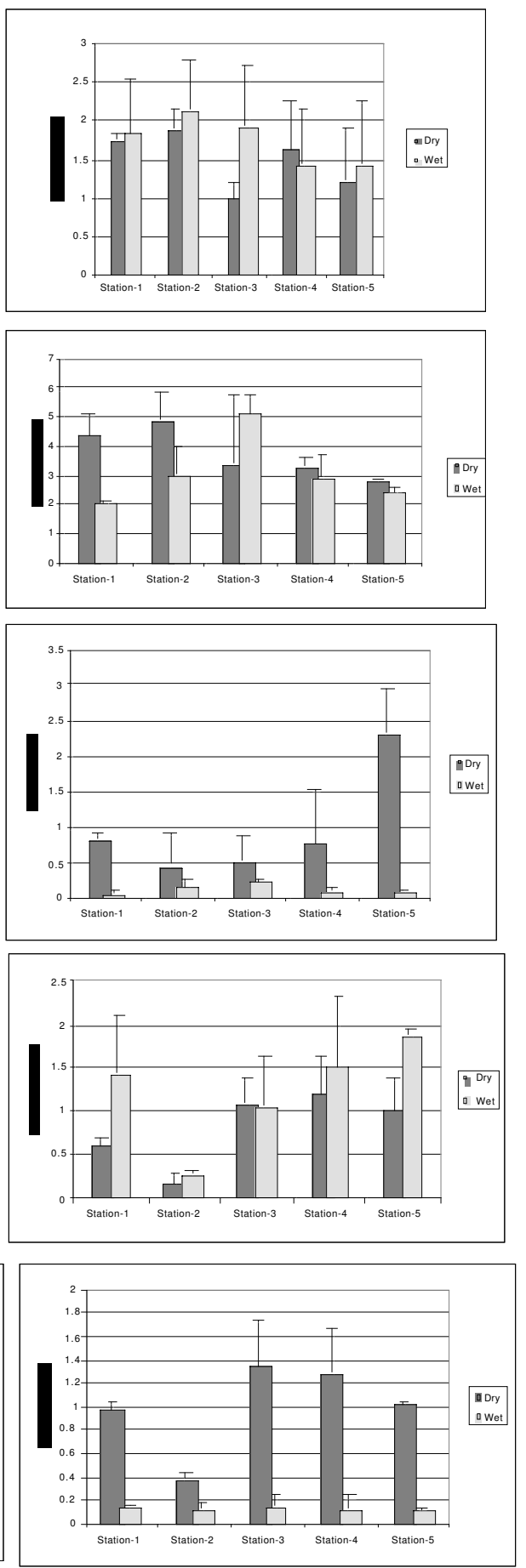

GRAFIC 1 - The physicochemical characteristics of the study stations for wet and dry seasons 
Water quality and periphyton community ofa stream system receiving municipal waste discharges in Rivers state, Niger Delta, Nigeria

\section{TABLE 1 - The periphyton species and their distribution pattern in the stream system.2}

\begin{tabular}{|c|c|c|c|c|c|}
\hline $\begin{array}{l}\text { Taxanomic group } \\
\text { (Family) }\end{array}$ & RARE & OCCASIONAL & COMMON & SUBDOMINANT & DOMINANT \\
\hline Bacillariophyceae & $\begin{array}{l}\text { Navicula lanceolata } \\
\text { Teipsinoe musica. } \\
\text { Eunotia gibbosa } \\
\text { Epectinalis } \\
\text { Navicula lanceolata } \\
\text { Pleurosigma elongatum }\end{array}$ & $\begin{array}{l}\text { Coconeis fluviattis } \\
\text { E. curvatus } \\
\text { E flexuosa } \\
\text { E lunafis } \\
\text { E monodon } \\
\text { Sururella elegans }\end{array}$ & $\begin{array}{l}\text { Amphora sp. } \\
\text { Coconeis fluviattis } \\
\text { Cymbella sp } \\
\text { Diatoma hiemale } \\
\text { Eunotia polydentula } \\
\text { E. gracilis } \\
\text { E. polyglyphis } \\
\text { E. praerupta } \\
\text { Fragillaria constwens } \\
\text { Frustufia rtiomboides } \\
\text { Gyrosigma scalproides } \\
\text { Gomphonema sp. } \\
\text { Navicula pusilla } \\
\text { Pinnularia inflata. } \\
\text { P. viddis } \\
\text { P. sublinearis } \\
\text { P. subcapitata } \\
\text { P. sublinearis. }\end{array}$ & $\begin{array}{l}\text { Achnanthes gibberala } \\
\text { A.flexella } \\
\text { A. inflata } \\
\text { A. grimmei } \\
\text { Cymbella sp } \\
\text { Diatoma biemale } \\
\text { Nitzschia acdcularis } \\
\text { Nitszchia. palea } \\
\text { Synedra acus. } \\
\text { S. ulna Kutr: } \\
\text { Tabellaria fenestrata } \\
\text { T floculossa }\end{array}$ & Achnanthes gibberala \\
\hline Chlorophyceae & $\begin{array}{l}\text { C. parvulum Nag. } \\
\text { Microspora flocossa } \\
\text { Mougeotia sphaerocarpa } \\
\text { Actinastrum sp } \\
\text { Oedogonium crassum } \\
\text { Pediastrum simplex } \\
\text { P. sp. }\end{array}$ & $\begin{array}{l}\text { Closterium gracile } \\
\text { C. lunula } \\
\text { Scenedesmus dubia. } \\
\text { Scenedesmus } \\
\text { quadrincauda } \\
\text { Ulothhx tenuissima. } \\
\text { U. zonata }\end{array}$ & $\begin{array}{l}\text { Cladophora oligodona. } \\
\text { Closterium acerosum } \\
\text { C. closteriodes } \\
\text { C. ebrenbergii } \\
\text { S. insignis. } \\
\text { S. karnalae }\end{array}$ & $\begin{array}{l}\text { Cladophora oligodona. } \\
\text { Closterium acerosum } \\
\text { C. closteriodes } \\
\text { C. ebrenbergii } \\
\text { S. insignis. } \\
\text { S. karnalae }\end{array}$ & \\
\hline Cyanophyceae & & $\begin{array}{l}\text { Oscillatoria sancta } \\
\text { Oscillatoria terebriformis } \\
\text { Phormidium brevis }\end{array}$ & $\begin{array}{l}\text { Oscillatoria granulata } \\
\text { Oscillatoria limosa } \\
\text { Oscillatoria } \mathrm{ph} . \text { nceps }\end{array}$ & $\begin{array}{l}\text { Lyngbya majuscula } \\
\text { Nostoc sp } \\
\text { Gleocapsa turgida } \\
\text { Gomphosphaen. s sp } \\
\text { isocystis plank.tonica } \\
\text { Lyngbya aeruginneo-coerulea } \\
\text { Lyngbya kutzingiana } \\
\text { Oscillatoria chalybalea } \\
\text { Oscillatoria pseudominma } \\
\text { Oscillatoria terebriformis }\end{array}$ & $\begin{array}{l}\text { Anacystis aeuroginosa } \\
\text { Anabaena flos aqua } \\
\text { Gleocapsa rupestris } \\
\text { Lyngbya } \\
\text { aeruginneo-coerulea } \\
\text { Lyngbya kutzingiana } \\
\text { Oscillatoria chalybalea }\end{array}$ \\
\hline Euglenophyceae & E. tripleris & $\begin{array}{l}\text { Phacus ostreatus } \\
\text { Ph. undulatup } \\
\text { Ph. pleuronectus } \\
\text { Ph. longicauda }\end{array}$ & $\begin{array}{l}\text { Euglena caudata } \\
\text { Phacus ostreatus } \\
\text { Ph. parvalus } \\
\text { Ph.onyx } \\
\text { S. urceolata } \\
\text { Trachelomonas elegans } \\
\text { T. mirabilis } \\
\text { T. armata } \\
\text { T. hispida }\end{array}$ & $\begin{array}{l}\text { E. tripleris } \\
\text { Eacus } \\
\text { Phacus ostreatus } \\
\text { Ph. parvalus } \\
\text { Ph.onyx } \\
\text { Strombomurias massartii }\end{array}$ & \\
\hline
\end{tabular}

The periphyton abundance demonstrated a clear seasonal variation with higher concentrations in wet season than in dry period particularly in some stations (2, 3 and 4) (Fig 3). The total abundance ranged from $7114-14784 \times 10^{5}$ indiv./ $\mathrm{cm}^{2}$. The maximum mean value for dry season was in station 5 with $14784 \times 10^{5}$ indiv. $/ \mathrm{cm}^{2}$ while the minimum mean in station (1) $7600 \times 10^{5} \mathrm{indiv} . / \mathrm{cm}^{2}$. In the wet period, the maximum density was obtained in station 4 was 14699 indiv. $/ \mathrm{cm}^{2}$. Studentt-test showed that differences between seasons were statistically not significant at $\mathrm{t}(0.043)<\mathrm{P}$ $(2.132)_{0.05}$. The chlorophyll "a" concentrations ranged from $10210.3 \pm 4206-110840.6 \pm$
$100226 \mathrm{mg} / \mathrm{cm}^{2}$ and $44657.94 \pm 38707.9-95275.25 \pm$ $66481.9 \mathrm{mg} / \mathrm{cm}^{2}$ for dry and wet seasons respectively. On spatial basis, dry season concentrations were higher in the upstream station $(88950.33 \pm 36723.3-110840.6 \pm 100226.4 \mathrm{mg} /$ $\mathrm{cm}^{2}$ ) than in the down stream stations $(10210.28 \pm 9206.4-75755.78 \pm 52893.4 \mathrm{mg} /$ $\mathrm{cm}^{2}$ ) and concentrations tended to decline down stream except for station 3 . In the wet season, a contrary spatial trend was observed with higher concentrations within the lower limit (95275.25 \pm 66481.9$\left.95299.39 \pm 40015.8 \mathrm{mg} / \mathrm{cm}^{2}\right)$ than at the upstream (70828.26 \pm 33655.6 - $72653.41 \pm$ $\left.43513.1 \mathrm{mg} / \mathrm{cm}^{2}\right)$ (Fig 5). 

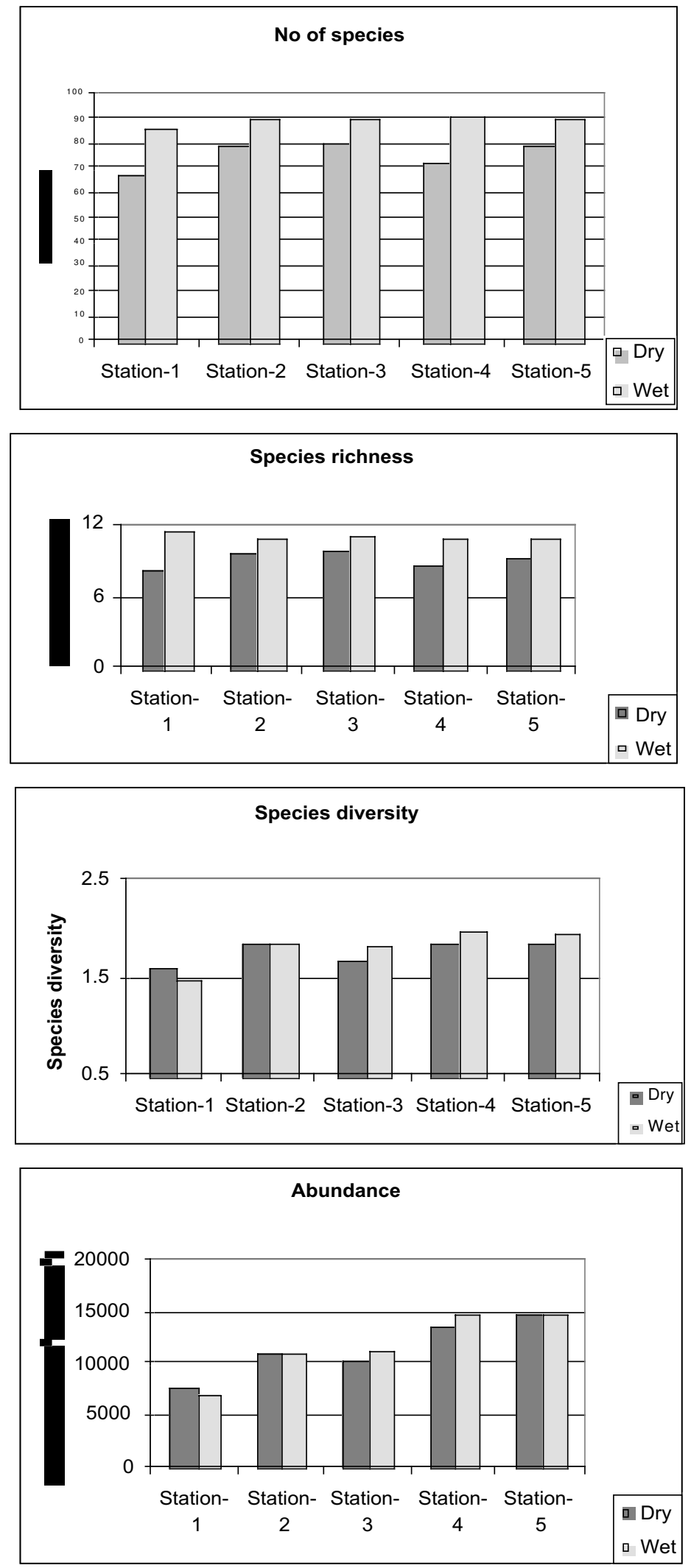

GRAFIC 2 - The distribution of periphyton descriptors for wet and dry seasons 
Dry

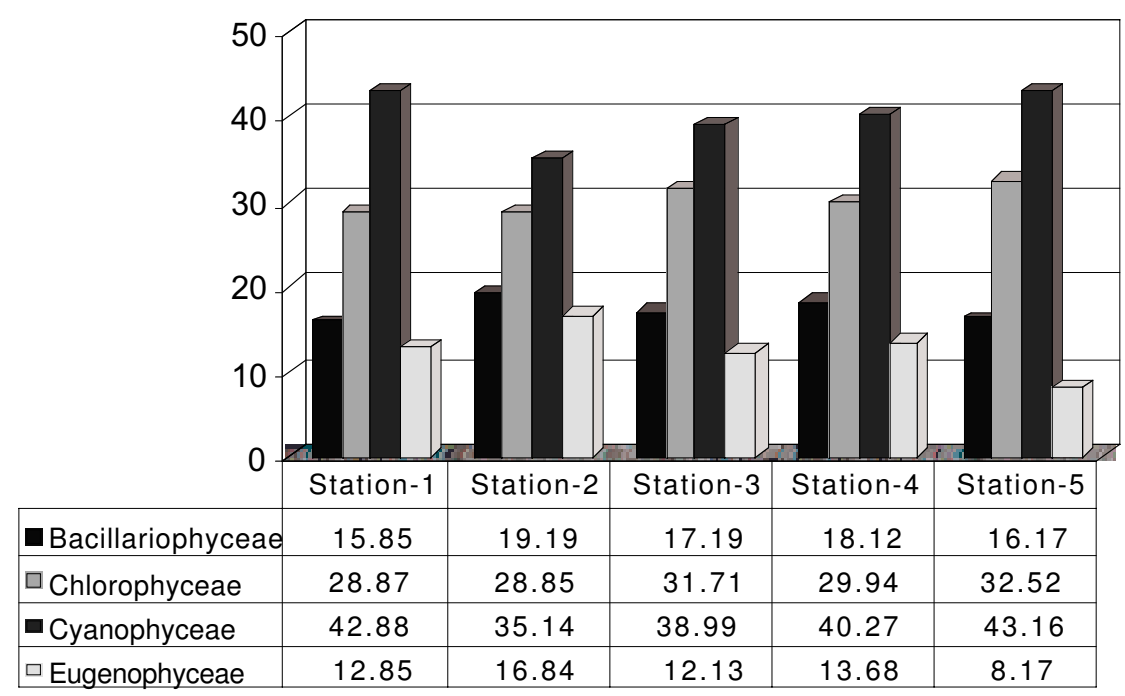

Wet

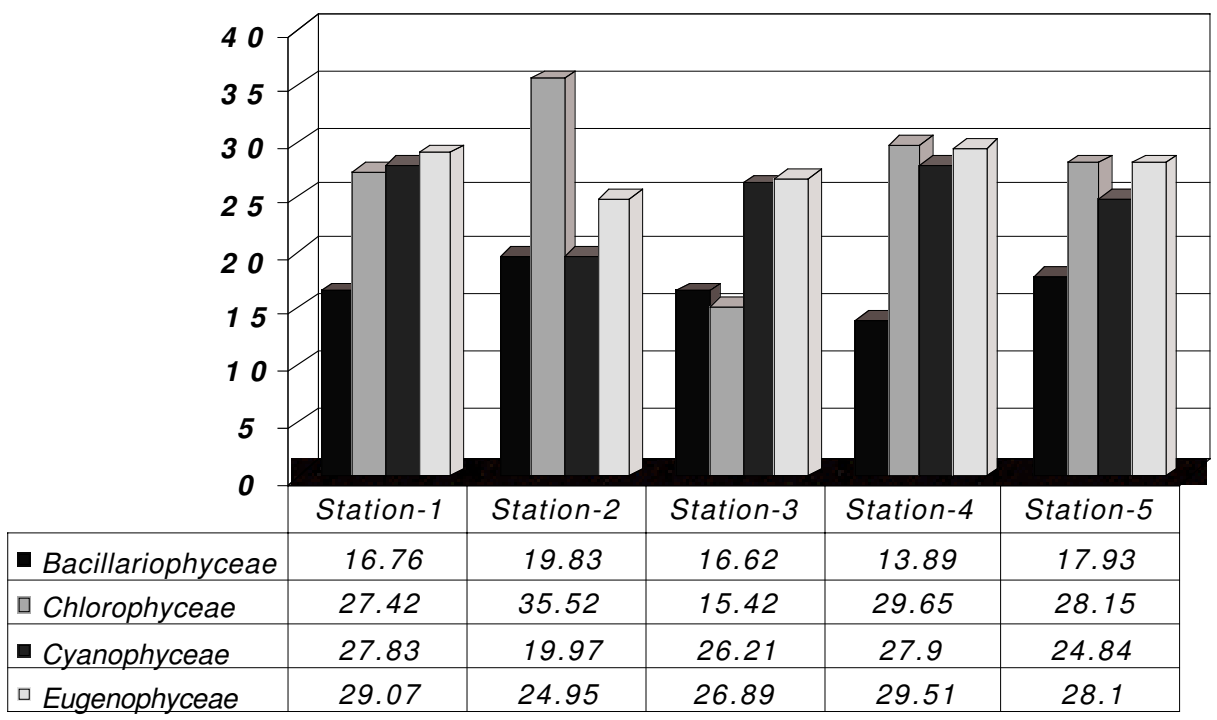

GRAFIC 3 - The relative composition of periphyton in dry and wet seasons during the study area 

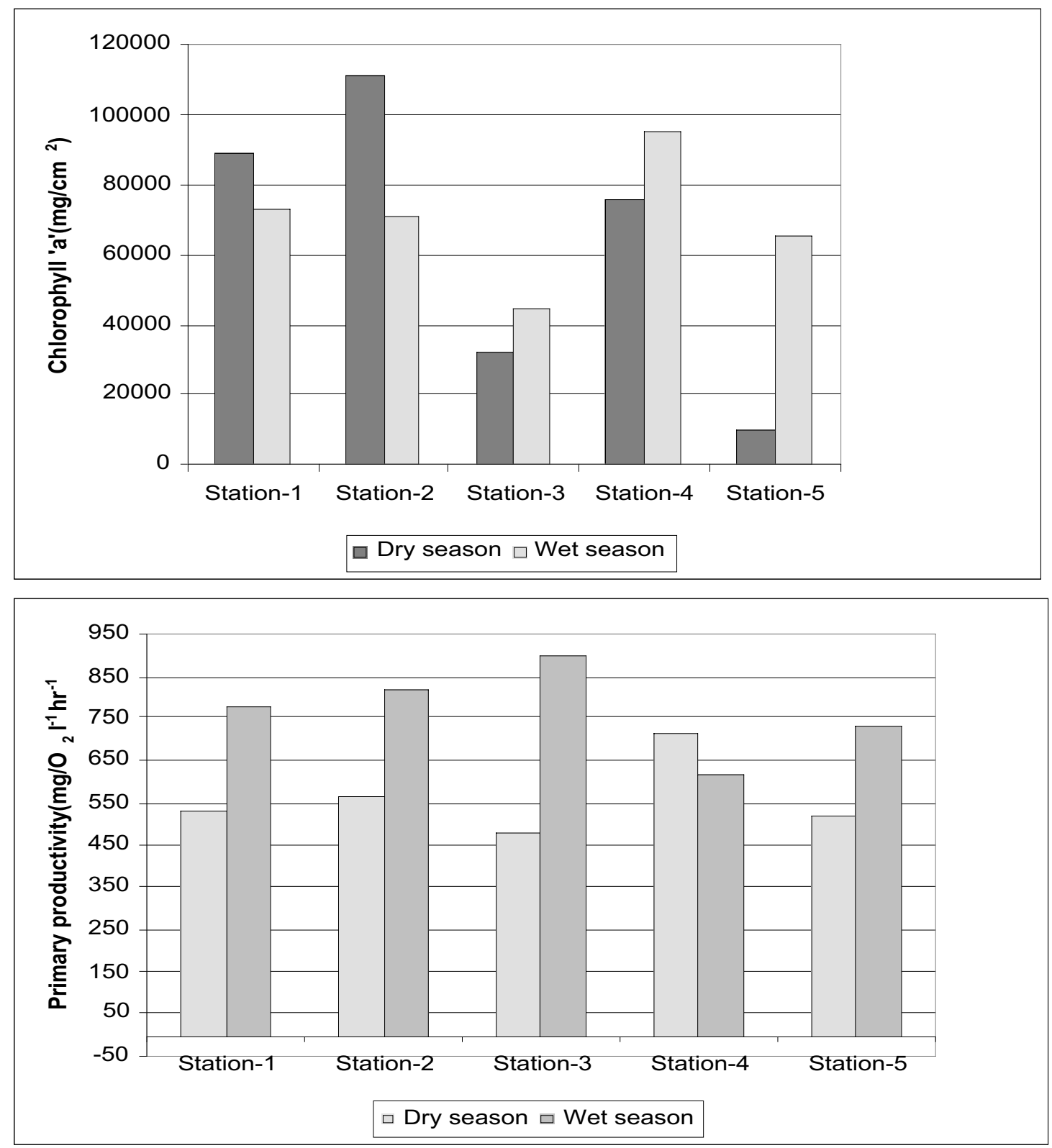

\section{GRAFIC 4 - The periphyton biomass (chlorophyll 'a') and primary productivity during dry and wet seasons in the study area}

Generally, differences between stations were statistically not significant Student t- test, $\mathrm{t}=$ $0.677<\mathrm{P}=2.92_{(0.05)}$ Primary productivity values for the entire study period varied from $479.17 \pm$ $235.6-711.67 \pm 417.8 \mathrm{mg} \mathrm{O}_{2} \mathrm{~L}^{-1} \mathrm{~h}^{-1}$ and $615.94 \pm$ 172- $901.098 \pm 398.9 \mathrm{mg} \mathrm{O}_{2} \mathrm{~L}^{-1} \mathrm{~h}^{-1}$ for dry and wet seasons respectively (Fig 2). In dry season, spatial differences indicated that the lower stations $\left(615.94 \pm 172-735.78 \pm 125.5 \mathrm{mg} \mathrm{O}_{2} \mathrm{~L}^{-1} \mathrm{~h}^{-1}\right)$ was marginally higher than the upstream limit but the reverse was observed in wet season with relatively higher concentrations in the upstream (777.0 \pm $\left.95.1-817.345 \pm 358.3 \mathrm{mg} \mathrm{O}_{2} \mathrm{~L}^{-1} \mathrm{~h}^{-1}\right)$ than in the down stream $(615.94 \pm 172-735.78 \pm 125.5 \mathrm{mg}$ $\mathrm{O}_{2} \mathrm{~L}^{-1} \mathrm{~h}^{-1}$ ) (Fig 5). The linear regression slopes for the some of the periphyton descriptors such as species number $\left(R^{2}=0.53\right)$ and species diversity $\left(\mathrm{R}^{2}=0.69\right)$ only demonstrated strong affinity (very close to 1) amongst stations in the wet season, while species richness demonstrated such close 
Water quality and periphyton community ofa stream system receiving municipal waste discharges in Rivers state, Niger Delta, Nigeria

TABLE 2 - The regressional trend of periphyton attributes for the wet and dry season

\begin{tabular}{|l|l|c|l|}
\hline & \multicolumn{3}{|c|}{ Periphyton descriptors } \\
\hline \multirow{3}{*}{ Number of species } & Dry & $1.6 \mathrm{x}+71$ & 0.24 \\
& Wet & $0.7 \mathrm{x}+87.5$ & 0.53 \\
\hline \multirow{3}{*}{ Species richness } & Dry & $-0.172 \mathrm{x}+11.47$ & 0.82 \\
& Wet & $0.125 \mathrm{x}+8.723$ & 0.11 \\
\hline \multirow{3}{*}{ Species diversity } & Dry & $0.058 \mathrm{x}+1.6$ & 0.42 \\
& Wet & $0.101 \mathrm{x}+1.509$ & 0.69 \\
\hline Chundance & Dry & $1710.2 \mathrm{x}+6368.6$ & 0.89 \\
& Wet & $1855.9 \mathrm{x}+6209.9$ & 0.88 \\
\hline Primary productivity & Dry & $-19256 \mathrm{x}+121262$ & 0.74 \\
& Wet & $6971.5 \mathrm{x}+54828$ & 0.68 \\
\hline & Dry & $12.837 \mathrm{x}+521.55$ & 0.05 \\
& Wet & $-28.391 \mathrm{x}+854.61$ & 0.18 \\
\hline
\end{tabular}

affinity between stations in the dry season $\left(\mathrm{R}^{2}=\right.$ 0.82) (Table 2).

But abundance (dry $-\mathrm{R}^{2}=0.8943$; wet $\left.\mathrm{R}^{2}=0.8847\right)$ and chlorophyll $\left(\right.$ dry $-\mathrm{R}^{2}=0.74$; wet $\left.-\mathrm{R}^{2}=0.68\right)$ demonstrated such affinity between stations at both seasons but such relationship were not observed with the primary producers at any of the seasons. Some relationship emerged between the physicochemical and periphyton descriptors such as the positive association between DO and abundance $(\mathrm{r}=0.767)$, and $\mathrm{BOD}_{5}$ and chlorophyll "a" $(\mathrm{r}=0.625), \mathrm{BOD}_{5}$ and abundance $(\mathrm{r}=0.646), \mathrm{SO}_{4}^{-2}$ and chlorophyll "a" $(r=0.621)$ (Table 3). Negative association was also observed between temperature and primary productivity $(r=-0.903)$, temperature and number of species $(r=-0.853)$ and temperature and species richness $(\mathrm{r}=-0.847), \mathrm{pH}$ and primary productivity $(\mathrm{r}=-0.784), \mathrm{pH}$ and number of species $(r=-0.671)$, and species richness $(r=$ -0.626), conductivity and number of species $(\mathrm{r}=-0.632)$ and species richness $(\mathrm{r}=-0.632)$, alkalinity and number of species $(r=-0.631)$, alkalinity and species diversity $(r=-0.656)$, phosphate and primary productivity $(\mathrm{r}=$ $0.819)$. Other negative association was between phosphate and species richness $(\mathrm{r}=$ -0.777 ), ammonia and primary productivity ( $\mathrm{r}$ $=-0.824)$, ammonia and species richness $(\mathrm{r}=$ - 0.829), ammonia and number of species ( $\mathrm{r}=$ $-0.785)$, nitrate and chlorophyll "a" $(\mathrm{r}=-0.630)$, sulphate and number of species $(r=-0.616)$ and nitrate and primary productivity $(\mathrm{r}=$ 0.765) (Table 3). 
TABLE 3 - The correlation matrix for physicochemical variables and periphyton descriptors for the seasons ns - not significant, $\square=$ significant

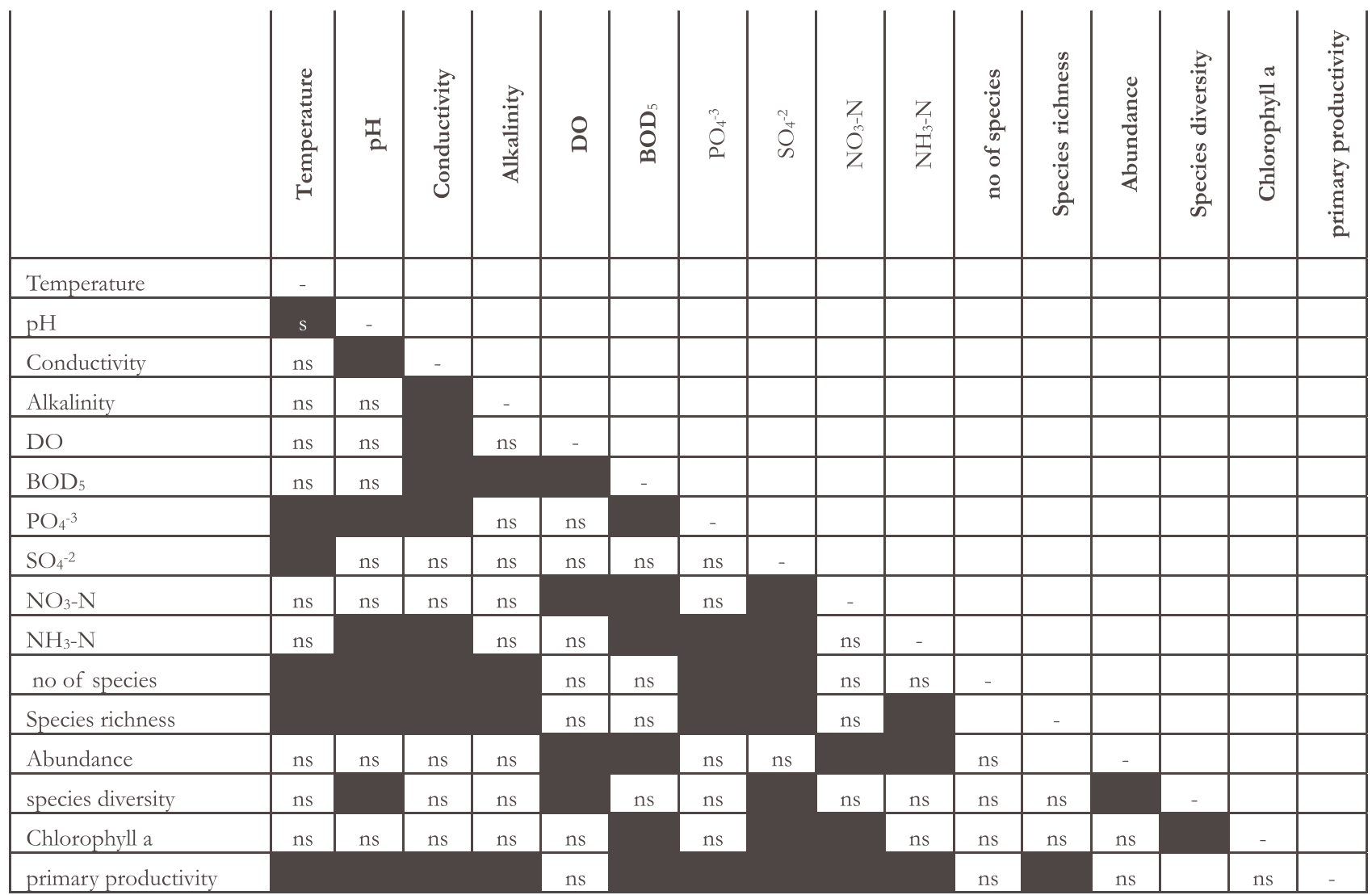

\section{Discussion}

The general high temperature and narrow variations within and between seasons observed in this study is expected as such characteristics had been reported in similar habitats in the Niger Delta $(18,19,20)$. This temperature pattern had been attributed to the location of the study area that lies within the equatorial tropical latitude where temperature variations between seasons are minimal (9), unlike the temperate latitude where seasonal variations in temperature often exceed $20^{\circ} \mathrm{C}$. Nevertheless, the relative differences in temperature between the lower and upper limits of the stream stretches may possibly be due to the differences in the relative forest cover as the lower limit stations are essentially open and neither uncovered by macrophytes nor vegetation. The acidic pH observed in the stream is expected and has been reported in similar stream systems where litter fall underlying the stream bed impacts on the water, through the process of decay; introduce humic substances that induce acidic condition (3). This feature is one of the common characteristics of swamp forest streams in the Niger Delta $(3,18)$. The conductivity values observed was above the expected limit of $25 \mu \mathrm{S} / \mathrm{cm}$ for such soft acid fresh swamp stream system (18). This may be associated with the adjoining discharges from the surrounding landmass activities along the course of the stream such as domestic effluent waste discharges, leachates from concrete structures and other related materials which may possibly contain lots of solutes and other dissolved compounds which are responsible for the elevated conductivity values, particularly at the lower limit sector of the stream stretch. The change in the relative conductivity concentrations also accounts for the establishment of a gastropod species (Pila $s p$.) that were hitherto absent in the past in the water body 
that was prominent at the time of study. Correspondingly the alkalinity values demonstrated similar trend observed for conductivity being symptomatic of the strong affinity between the two water quality attributes. The relative high concentration of dissolved oxygen in the system may in part be associated with the exposed nature of the stream (by forest or macrophyte cover) which allows sufficient aeration by wind, local eddies and perhaps high concentrations of primary producers which through photosynthetic process contribute to the relative high oxygen concentrations observed for the water body. Other studies in the eco-region have indicated lower dissolved oxygen concentration for similar water bodies. RPI (18) reported values less than $4.0 \mathrm{mg} / 1$ for Warri River at Agbahor, Chindah (21) recorded concentrations of $5.0-6.1 \mathrm{mg} / 1$ for Elele-Alimini stream and IPS reported $3.2-4.8 \mathrm{mg} / \mathrm{l}$ for Ebubu Ochani stream. However, these water bodies are considered relatively shaded stream systems (covered by forest canopy) with low nutrient status as against the Ntawogba stream which receives regular nutrients from the municipal discharges. However, seasonal differences in dissolved oxygen were observed with higher concentrations in wet than in the dry season. This further gives impetus to the proposition that the increased current inflow during the wet season facilitates increased wave actions eddies and diffusion of atmospheric oxygen that contribute to the elevation of the oxygen concentration during the corresponding period. This scenario had been reported in fresh and brackish waters of the Niger delta $(8,18,22)$. Sulphate concentrations were higher than concentrations reported for similar swamp forest water bodies (18). The high sulphate concentration may be attributed to the combined effect of effluents from industrial and municipal sources which may be characteristically rich in sulphate related compounds $(20,23)$. The concentrations of nitrate and phosphate were comparably higher with a magnitude of $1_{-}-2$ relation with concentration observed in the same system years ago (2). The relative increase may be associated with the increased industrial and domestic discharges into the water body. The natural low nutrient in the past was linked to the nature of the bed rock which is generally not rich in nitrate and the relative low $\mathrm{pH}$ which reduced the availability of nitrate in the system $(24,25)$.
Chindah and Nduaguibe (23) and Chindah (26) had posited that high temperature and activities of primary producer's such as algae and other microbial biomass quickly strip the water bodies of its nutrient load. This deduction is supported by the fact that considerable high level of nitrate and other nutrients that were observed in the lower limit stretch where the domestic runoff or discharges are overwhelmingly higher than the uptake by the primary producers. Ammonia concentrations that were relatively high and above national standards for water quality fell within the toxic limit for periphyton (27). This scenario is not the case with our study on the periphyton population in natural environment and may be due to the maturation age of the periphyton and possibilities of the occurrence of adaptive species. Niederlehner and Cairns (27) contended that advanced stages of periphyton exhibit greater stress tolerance such as the high ammonia level and this scenario had been observed in terrestrial plant community (28).

The 92 periphyton species recorded in this study are slightly higher than that observed for other substrate types and water body such as in Lagos Lagoon where fifty species each where recorded for submerged aquatic macrophysics - Hornwort and Bladder (29) and floating log (30). The values were close to that observed in the tidal fresh water ecosystem of the New Calabar River where 110 species were recorded in Crinium plant (2). The disparity observed in this study can be associated in part to the nature of the water body and substrate types and secondly to the duration of exposure / age of the periphyton community $(3,8,26,31)$. The relative high periphyton species observed in Nta-Wogba stream against the values observed in the other freshwater systems in the Niger Delta (3, $32)$ is an indication that the waste water discharges may have enhanced its development and sustainability in the environment and over time resulted in the stability of the periphyton population. The slight differences in algal assemblages between stations may be explained in part to the microhabitat differences in water quality, which corresponded to the colonization of some species particularly the filamentous green and blue greens that appeared more obvious in the lower stretch of the stream where more waste 
water discharges are putative. Thus the abundance of the blue green algae-Cyanophyceae in Stations 3 and 4 may in part be due to the fact that the area have activities such auto mechanic workshops and other domestic discharges and also the dominance of the blue green algae at the system suggests that it has out competed other algal forms due to its ability to tolerate stress condition especially in oil polluted environment as reported by Pudo (33). Also the variation observed in the dominant species types may be attributed to the difference between the ecological locations and quality of recipient effluent into each of the study stations. This suggests that indicator species may vary from one ecological area to the other based on the variability between stations and other unique matrix of habitat constraints that characterize freshwater systems may be contributory to the disparity observed Biggs et al. (34). The close affinity in the distribution of the periphyton descriptors amongst the stations either at a particular season or both indicates the role of season in defining allotment of the periphyton attributes in the system (19, 23). The negative correlation values for the periphyton productivity and $\mathrm{pH}$ suggest that $\mathrm{pH}$ is not suitable for periphyton productivity. Also the negative association between periphyton descriptors and nutrients may be as a result of the stationary nature of periphyton population and the differences in their niche requirements. Jones (35) posited that humic acid substances react with other dissolved substances such as phosphorous, reducing their bioavailability. It is therefore possible that diatoms disperse along a continuum from endemic species to cosmopolitans depending on ecological tolerance body size and life form. The general trend of the community structure pattern of Bacillariophyceae > Cyanophyceae > Euglenophyceae $>$ Chlorophyceae had been the trend reported for most freshwater system with limited disturbance but the deviation from this general trend at most of the down stream stations is an evidence of perturbation. The ability and capacity of blue green algae such as Anacystis aeuroginosa to reach such unpropitious nuisance levels, implies that the water at the lower reach had attained eutrophic status and similar scenario had been reported in the literature to periphyton communities in waters bodies polluted by crude oil spills and municipal effluents (1, 19, 36). This shift appears to be induced by the relative differences in nutrient status of the stations and implies that the organism especially those of bluegreen and euglinin origin have opportunistically taken the advantage to dominate other forms in the periphyton community (19). Hart and Finelli (37) argued that discharge regime frequently plays an overriding role in the regulation of production, biomass and community composition of benthic organisms. This contention may apply to the observed changes in the periphyton community structure of the environment investigated as such variability in community structure was observed at areas with reputed high waste water discharges. Hillebrand et al. (38) posited that changes in community structure also results in changes in the species richness and diversity but this was not the case in this study. The differences observed in this study with that of Hillebrand et al. (38) may be linked with habitat variability and the age of the periphyton community as the values obtained in this study were based on natural system. The high abundance, biomass and primary production of periphyton observed in this study may be associated with three distinct processes. Firstly, on account of the response of the periphyton algae to the steady nutrient input that contributes to the development and growth of algae as reported by Vymazal (39) and Steinman et al. (40). The second process which may be important but was not fully quantified in this study was on the basis of the hydrological process of the system that is characterized by a relatively low magnitude of flow velocity and the attendant limited shear stress on the periphyton community that will be incapable of dislodging the periphyton encrusting algal mass. Tett et al. (41), Steinman et al. (42) and Smolar et al. (43) reported that increase in flow velocity, wash away loosely adhering periphyton. This contention was also reported by Chindah (19). This is affirmed from the seasonal differences in the periphyton population densities, biomass and productivity with greater magnitude observed in dry season than in the wet season when current velocity is expectedly at its minimum; and the lack of significant differences between the seasons on these attributes suggests the limited effect of it on the periphyton attributes described and thirdly being perhaps to less exploitation of the periphyton by browsers particularly fish which appear to be low very in 
the water body. Other studies had similarly attributed such high densities as observed in this study to discharge and velocity of water, roughness of the substrata, and biological characteristics of algal species $(44,45,46,47,48,49,50,51,52,53$, $54,55)$. The results generally showed that though the introduction of industrial and domestic effluents appeared to have altered the physicochemical characteristics of the stream system (Nta-wogba stream), seasonal differences were not very obvious. On the other hand changes in biological parameters such as abundance, biomass and primary productivity of periphyton were more reliably affected.

\section{References}

1. Amadi EN, Chindah AC, Ugoh, CC. The effect of municipal drainage on the microflora of a Black Water Stream in Port Harcourt, Nigeria. Niger Delta Biologia. 1997; 2(1):125139.

2. Chindah AC, Hart AI, Uzoma AI. Periphyton associated with submerged macrophytes (crinium natans) in in the upper reaches of the New Calabar River Niger Delta. J of Agric. Biotec. \& Environment. 1999; 1(2):37-46.

3. Chindah AC. Epipelic algae of tropical estuary: Case of stable and invariable seasonally community. Pol J Ecology. 2003a; 51(1):91-99.

4. Obunwo CC, Braide SA, Izonfuo WAL, Chindah AC. Influence of urban activities on the water quality of fresh water streams in the Niger Delta, Nigeria. Journal of Nigerian Environmental Society (JNES). 2004; 2(2):196-209.

5. Izonfuo WAL, Chindah AC, Braide SA, Lawson DA. Physicochemical Characteristics of Different Ecotonal Streams In A Rapidly Developing Metropolis In The Niger Delta, Nigeria . Caderno de Pesquisa . Ser Bio Santa Cruz do Sul. 2005; 17(2):91-105.

6. Obot EA, Chindah AC, Bradie SA. Vegetation recovery and herbaceous production in a fresh water wetland 19years after a major oil spill. Afr J Ecol. 1992; 30:149-156.
7. Nwankwo DI. periphyton algae on fish fence $s$ (Acadja) in a tropical open lagoon. Intern. J. of Ecology and Environmnetal Sciences. 1991; 17:1-10.

8. Chindah AC, Braide SA. The physicochemical quality and phytoplankton community of tropical waters: A case of 4 biotopes in the lower Bonny River, Niger Delta, Nigeria. Caderno de Pesquisa. Ser Bio Santa Cruz do Sul. 2004; 16(2):7-37.

9. Gobo AE. Relationship between rainfall trends and flooding in the Niger Delta Benue basin. J Metrrology uk. 1988; 13(37):813-828.

10. APHA- American Public health Association. Standard methods for the evaluation of water and waste water. $2^{\text {nd }} \mathrm{ed}$, Washington: Americam Public Health. Association; 1998.

11. Mills FW. Some diatoms from Warri River Southern Nigeria. J Royal Microsc. 1932; 853:382-395.

12. Sieminska J, Chrysophyta II. Bacillariophyceae Okrzemkii: In: Starmach K (ed) Flora S lodkuwodn: Polski (Freshwaterr Flora of Pokind) 6. WARSZAWA, Pan'stwowe Wydawinctwo Naukowe; 1964. 610 p.

13. Starmach K. Cyanophyta-Since, Glaucophyta-glaukifity In: Flora. Slokuwodna Polski. STARMARCH K. Pan'stwowc Wydawinctwo Naukowe, Warzawa; 1966. v. 2. 808 p.

14. Patrick R, Reimer C. The diatoms of the Uninted States ecxlucive Alaska and Hawaii, Eunotiaceae, Achnanthaceae, Naviculaceae. Philadelphia: Livingstone Publ Com; 1966.

15. Durand JR, Leveque C. Flore et Faunae Aquatiequies de l' Afrique. Cah Off Res Sci TechOutre Mor. 1980; 1:5-46.

16. Chindah AC, Pudo J. A preliminary checklist of algae found in plankton of Bonny River in Niger Delta, Nigeria: Fragm flor Geobot. 1991; 36(1):112-126.

17. Margalef R. Information Theory in ecology. Gen Sys. 1958; 3:50-71.

18. RPI - Reseasch Planning Institute, Columbia South Carolina, USA. Environmnetal Baseline Studies for the establishment of Control Criteria and Standars against Petroleum Related Industries in Nigeria; 1985. RPI/R/84/4/15-17. 
19. Chindah AC. The effect of industrial activities on the periphyton community of upper New Calabar River. Nigeria: Water Res. 1998; 32(4):1137-1143.

20. Braide SA, Izonfuo WAL, Adiukwu PU, Chindah $A$ C, Obunwo CC. Water quality of Miniweja stream, a swamp forest stream receiving non point source waste discharges in eastern Niger Delta, Nigeria. Scientia Africana. 2004; 3(1):1-8.

21. Chindah AC. The physico-chemistry phytoplankton and periphyton of a swamp forest streams in the lower Niger Delta. Scientia Africana. 2003c; 2(1, 2):106-116.

22. NDES - Niger Delta Environmental Survey. Ecological zonation and habitat classification of the Niger Delta region. A report of NDES (an NGO) on the ecological status of the Niger Delta. [S.1: s.n.]; 2001.

23. Chindah AC, Nduaguibe U. Effects of tankfarm waste water on water quality and periphyton lower Bonny River, Niger Delta, Nigeria. Journal of Nigerian Environmental Society (JNES); 2003. 1(2):206-222.

24. Fisher SG, Summer ST. Fort basin ecosystem: productivity of the periphyton component; 1976. NTISPB $278-772$.

25. Grimm NB, Fisher SG. Nitrogen limitation in a Sororan Desert stream. J North Am Benthol Soc. 1986; 15:2-15.

26. Chindah AC. The physico-chemistry phytoplankton and periphyton of a swamp forest streams in the lower Niger Delta. Scientia Africana. 2003b; 2(1, 2):106-116.

27. Niederlehner BR, Cairns J. Effects of Ammonia on periphytic communities. Environmnetal Pollution. 1990; 66:207-221.

28. Woodwell GM. Recycling sewage through plant community. Am Sci. 1977; 65:556562.

29. Nwankwo DI, Onitiri AO. Periphyton on submerged aquatic macrophytes (Hornwort and Bladderwort) in Epe Lagoon. J Agric Sci Technol. 1992; 2(2):135-141.
30. Nwankwo DI, Akinsoji A. Epiphytic community on water hyacinth -Eichhornia crassipes (Mart.) Solms in coastal waters of Southwestern Nigeria. Arech Hydrobiol. 1992; 124:501-511.

31. Erondu ES, Chindah AC. Physico-chemical and phytoplankton changes in a tidal freshwater station of the New Calabar River, South Eastern Nigeria. Environment \& Ecology. 1991; 9(3):565-570.

32. Chindah AC, Braide SA, Amadi EN, Osuamkpe A. Investigations into the Epipelic algal community of Elechi creek at Bonny Estuary, Niger Delta. Nigeria: Intern J Biochemiphysics. 1993; 2(1, 2):119-124.

33. Pudo J. Investigation on algae in the o i 1 spilled region of the Bonny River. In: Proc. Ecolog. Society of Nigeria Annual Conference. Nigeria: Port Harcourt; 1985. p. 171-177

34. Biggs BJF, Stevenson RJ, Lowe BL. A habitat matrix conceptual model for stream periphyton. Arch Hydrobiol. 1998; 143:21-36

35. Jones RI. Phosporus transformations in the epilimnion of humic lakes biological uptakes of phosphate. Freshwater Biol. 1990; 23:323-337.

36. Pudo J, Fubara DMJ. Studies on Periphyton Algae in the Petroleum Oil Spillage Area of the Niger Delta aquatic System. Verh Int Ver Limnol. 1988; 23:2259-2261.

37. Hart DD, Finelli CM. Physicobiologgical coupling in stream: The pervasive effect of flow on benthic organism. Annu Rev Ecol Syst. 1999; 30:363-395.

38. Hillebrand H, Watermann C, Karez R, Berninger UG. Differences in species richness patterns between unicellular and multicelluar organisms. Ecologgia. 2000; 126:114-124.

39. Vymazal J. The use of periphyton communities for nutrient removal from polluted streams. Hydrobiologia. 1988; 166: 225-237.

40. Steinman AD, Mulholland PJ, Hill WR. Functional responses associated with growth form in stream algae. J N Am Benthol Soc. 1992; 11:229-243. 
41. Tett P, Gallegos C, Kelly MG, Hornberger GM, Cosby GJ. Relationships among substrate flow amd benthic microalgal pigment density in the Mechums River Varginia. Limnol and Oceanogr. 1978; 3(4):785-797.

42. Steinman AD, McIntire CD. Effects of current and light energy on the structure of periphyton assemblages in laboratory streams. J Phycol. 1986; 22:352-361.

43. Smolar N, Vrhovsek D, Kosi G. Effects of low flow on periphyton in three different types of streams in Slovenia. In: Bretschko, G., Hele`sic, J_. Advances in River Bottom Ecology. Leiden, Netherlands: Backhuys Publishers; 1998. p. 107116.

44. Horner RR, Welch EB. Stream periphyton development in relation to current velocity and nutrients. Can J Fish Aquat Sci. 1981; 38:499557.

45. Horner RR, Welch EB, Seeley MR, Jacoby JM. Response of periphyton to changes in current velocity, suspended sediment and phosphorus concentration. Freshwat Biol. 1990; 24:215-232.

46. Bergey EA, Boettiger CA., Resh VH. Effects of water velocity on the architecture and epiphytes of Cladophora glomerata (Chlorophyta). J Phycol. 1995; 31:264-271.

47. Biggs BJF, Thomsen HA. Disturbance of stream periphyton by perturbations in shear stress: time to structural failure and differences in community resistance. J Phycol. 1995; 31:233-241.

48. Quinn JM, Hickey CW, Linklater W. Hydraulic influences on periphyton and benthic macroinvertebrates: simulating the effects of upstream bed roughness. Freshwat Biol. 1996; 35:301-309.
49. Chindah AC, Braide SA, Onwuteaka JN. Vertical distribution of periphyton in on woody substrate in a brackish wetland embayment of Bonny river, Niger Delta. Delta Biologia. 2005; 5(1):97108.

50. Izonfuo WAL, Chindah AC, Braide SA, Lawson DA. Physicochemical Characteristics of Different Ecotonal Streams In A Rapidly Developing Metropolis In The Niger Delta, Nigeria. Caderno de Pesquisa. Ser Bio Santa Cruz do Sul. 2005; 17(2):91-105.

51. Nwankwo DI, Akinsoji A. Periphyton algae iof Eutrophic creek and their possible use as indictors. Nigerian J of Botany. 1988; 1:96-105.

52. Pudo J. Ekologiczne skiki zanicezyszcznia ropa naflowa poludniowej Nigerii (South Nigeria ecological consequence of crude oil water pollution) Gosp Wodna. 1989; 4: 85-87.

53. Rosemond AD. Multiple factors limit seasonal variation in periphyton in a forest stream. J North Am Benthol Soc. 1994; 13:333-344.

54. Stevenson RJ, Peterson CG. Emigration and immigration can be important determinants of benthic diatom assemblages in streams. Freshwat Biol. 1991; 26:279-294.

55. Smoot JC, Langworthy DE, Levy M, Periphyton growth on submerged artificial substrate as a predictor of phytoplankton response to nutrient enrichment. J Microbiol Methods. 1998; 32:11-19.

Recebido em/Received in: February 23, 2006. Aprovado em/Accepted in: March 31, 2006. 